\title{
Chromatin Remodeling Factor
}

National Cancer Institute

\section{Source}

National Cancer Institute. Chromatin Remodeling Factor. NCI Thesaurus. Code C18602.

The proteins or protein complexes that can either activate or silence gene transcription through their ability to modify the architecture of chromatin. These factors alter the accessibility of DNA to those factors that are required for gene transcription. 